\title{
Variation of Nutritional and Anti-Nutritional Contents in Finger Millet (Eleusine coracana (L.) Gaertn) Genotypes
}

\author{
Solomon Igosangwa Shibairo ${ }^{*}$, Oliver Nyongesa ${ }^{1}$, Richard Onwonga ${ }^{2}$ and \\ Jane Ambuko ${ }^{1}$ \\ ${ }^{1}$ University of Nairobi, College of Agriculture \& Veterinary Sciences, Department of Plant Science and Crop \\ Protection, P.O Box 29053-00625, Kangemi, Nairobi \\ ${ }^{2}$ University of Nairobi, College of Agriculture \& Veterinary Sciences, Department of Land Resource \\ Management and Agricultural Technology, P.O Box 29053-00625, Kangemi, Nairobi
}

\begin{abstract}
Variation in nutritional and anti-nutritional contents among six finger millet genotypes was determined. Improved finger millet genotypes Gulu-E and FMV-1 from Kenya Agricultural Research Institute, KNE-479 and KNE 1034 from International Crops Research Institute for Semi-Arid Tropics (ICRISAT) and local landraces Ateso and Nyaikuro, were compared. There was no significant ( $p>0.05)$ difference in calcium $(\mathrm{Ca})$, iron ( $\mathrm{Fe}$ ) and zinc (Zn) contents among the genotypes. Genotypes Ateso and Gulu-E had the highest crude fat contents while KNE-479 had the lowest. Genotypes KNE-479 and Nyaikuro had the highest crude protein content. Lowest crude protein contents were observed in genotypes Gulu-E and Ateso. Genotype Ateso followed by FMV-1 and Nyaikuro had high isoleusine, leusine, methionine, threonine and cysteine amino acid contents. High levels of phenylalanine were observed in genotypes Nyaikuro and Ateso. Ateso had the highest Phydroxybenzoic, sinapic and syringic acids, while Nyaikuro had high ferulic and vanilic acids. Except for genotype KNE-479 with highest sinapic acid contents, the ICRISAT developed genotypes had the lowest antinutritional contents. Anti-nutrients tannins, vanilic acid and ferulic acid were negatively correlated to Fe and $\mathrm{Zn}$ contents. Therefore when selecting finger millet for Fe and Zn the levels of anti-nutritional contents need to be considered.
\end{abstract}

Key words; anti-nutritional contents, finger millet, genotypes, nutritionals factors

\section{Introduction}

Finger millet (Eleusine coracana) is an important food and fodder crop in arid and semi-arid lands (ASALs) of Africa and Asia where it performs well than other cereals ([1];[2]). Because of its ability to tolerate drought under poor soil conditions, it is deemed an important crop to increase food security in ASALs ([3]). Among the major food grains, finger millet is one of the most nutritious crops as it contains high quality minerals (calcium $(\mathrm{Ca})$ and iron $(\mathrm{Fe})$ ) and amino acids (methionine, an amino acid lacking in the diets of hundreds of millions of the poor who live on starchy foods such as cassava, plantain, polished rice and maize meal); and provides 8-10 times more $\mathrm{Ca}$ than wheat or rice ([4]; [5]). Calcium deficiency leading to bone and teeth disorder, Fe deficiency leading to anemia can be overcome by introducing finger millet in our daily diet ([6]). Finger millet also has medicinal attributes used by diverse communities for making special foods for diabetics, gluten-free food for people suffering from celiac disease and weaning foods for infants ([7]). Starch fractions in finger millet are slow in digestion and absorption hence favorable in the diet pattern for metabolic disorders such as diabetes, hypertension, and obesity ([8]).

Maximum utilization of the nutrient potential of finger millet may be limited by the presence of antinutritional compounds such as phytates, phenols, tannins and enzyme inhibitors ([6]). Even though they play an important role in biological functions of plants, in human and animals anti-nutritional compounds are partly negative because they reduce the digestibility of nutrients and the absorption of minerals ([9]). They may also inhibit growth as a result of their negative influence on the function of pancreases and the thyroid gland, and can cause pathological alterations in the liver. Tannin compounds affect color, flavor and nutritional quality of the grain and products prepared from it ([10]). Phytic acid complex combine with essential dietary minerals such as $\mathrm{Ca}$, zinc $(\mathrm{Zn}), \mathrm{Fe}$ and magnesium $(\mathrm{Mg})$ to make them biologically unavailable for absorption. A number of recently improved (bred) genotypes have been developed for drought conditions in Kenya. However, the relationship between genotype and nutritional and anti-nutritional compounds of the genotypes has not been determined. The objective of this study was therefore to determine nutrient and anti-nutritional contents and their relationship among finger millet genotypes. 


\subsection{Sources of Materials}

\section{Materials and Methods}

Finger millet genotypes were chosen following an on-farm experiment conducted at Katangi location of Machakos County in eastern Kenya. The Katangi farm lies on the grid 01.34133S; 007.64623E with an altitude of $1600 \mathrm{~mm}$ (a.s.1). The region is drier and experiences an annual rainfall ranging between $300-650 \mathrm{~mm}$ with $40 \%$ reliability while evaporation rates ranging between (1800-2000 mm/year) ([11]). Six genotypes from different sources were selected based on their drought tolerance and yield performance during the 2012/2013 planting season. They included improved finger millet genotypes Gulu-E and FMV-1 from Kenya Agricultural Research Institute (KARI), KNE-479 and KNE 1034 from International Crops Research Institute for Semi-Arid Tropics (ICRISAT) and Ateso and Nyaikuro as the local landraces. Genotypes Ateso, Gulu-E and FMV-1 were selected as high yielders while KNE-1034, KNE-479 and Nyaikuro as low yielders. In the field experiment, the genotypes had been put as main plots of a split-plot arrangement in a randomized complete block design, with the treatments replicated thrice.

\subsection{Preparation of materials}

After harvesting, finger millet was sun-dried for 5 days to a moisture content of $12-13 \%$ and to constant weight. The chuff was removed after threshing by winnowing to ensure clean grain that is free from foreign material. A mass of $50 \mathrm{~g}$ of each sample was weighed and labeled. The samples were then grounded to a fine powder ready for analysis.

\subsection{Measurement of Variables}

\subsubsection{Mineral contents}

Calcium, Fe, and $\mathrm{Zn}$ contents were determined on 5.0g finger millet sample which was weighed and oven dried overnight at $110^{\circ} \mathrm{C}$. Organic materials from the sample were removed by dry-ashing, then the residue was divided into three replicates (portions) containing $0.1 \mathrm{~g}$ of each sample. The mineral contents were determined by the procedure of [12].

\subsubsection{Proximate composition analysis}

Proximate composition analysis included moisture content, crude protein, crude fat, carbohydrate content, energy content and total ash content and crude fiber.

Moisture content was determined on $5.0 \mathrm{~g}$, in triplicates, samples of finger millet as described by $([13])$

Crude Protein was determined on $0.5 \mathrm{~g}$ fresh finger millet grain samples, in three replications, by ([12]).

Amino acids in finger millet were determined on samples of $3.0 \mathrm{~g}$ of finger millet in triplicates using Gas Chromatography- Mass Spectrometry (GC-MS) analytical method ([12]). by $([13])$.

Crude fat content was determined on $3.0 \mathrm{~g}$ weight of finger millet flour samples by a method described

Total carbohydrate contents of raw and processed finger millet cultivars were calculated from the equations described in [14]).

Total energy was determined by calculation from fat, carbohydrate and protein contents using as described in [15] and [12]). Finger millet flour sample of $2.5 \mathrm{~g}$, in triplicates, was put in dishes and total ash content was determined by a method described by ([16]).

Crude fiber was determined by digesting $5.0 \mathrm{~g}$ of finger millet flour in triplicates, as described by [12]) and [13]).

\subsubsection{Anti-nutritional contents}

Anti-nutritional contents were determined on finger millet grains after they were manually hulled and ground to obtain a fine powder; and six phenolics; sinapic, ferulic, $p$-hydroxybenzoic, syringic, salicylic, $p$ coumaric, and vanillic acids determined by a method described by ([17]).

\subsection{Data analysis}

The data were subjected to analysis of variance (ANOVA) using Genstat statistical package version 18 and means separated by least significant difference at $\mathrm{P}=0.05$. Duncan's multiple range tests was used to compare the means. Correlation tests between nutritional and anti-nutritional contents were done. 


\subsection{Mineral Contents}

\section{Results}

Calcium, Fe and $\mathrm{Zn}$ mineral contents were not significantly different ( $\mathrm{p}>0.05)$ among genotypes (Table1). Calcium content had a mean content of $2944 \mathrm{mg} / \mathrm{kg}$ while Fe and $\mathrm{Zn}$ contents averaged $98 \mathrm{mg} / \mathrm{kg}$ and $16.9 \mathrm{mg} / \mathrm{kg}$, respectively.

\subsection{Proximate composition}

Crude fat and crude protein contents significantly varied $(\mathrm{p}<0.05)$, while ash, carbohydrates, moisture, energy and crude fiber contents did not differ among the six finger millet genotypes (Table 2). The highest crude fat contents were observed in high yielding genotypes Ateso and Gulu-E. In contrast, the lowest crude fat content was observed in genotype KNE-479. Genotype KNE-479 had the highest crude protein content while genotypes FMV-1, Gulu-E and Ateso had the lowest crude protein contents.

Table 1: Calcium, Iron and Zinc contents in finger millet genotypes at Katangi in Machakos County

\begin{tabular}{lrrr}
\hline Genotypes & \multicolumn{2}{c}{ Mean of mineral contents in (mg/kg) } \\
Calcium & Iron & Zinc \\
\hline Ateso & 2968 & 120 & 20 \\
Gulu-E & 3199 & 33 & 15.3 \\
FMV-1 & 2875 & 40 & 15.3 \\
KNE-479 & 2736 & 137 & 16.9 \\
KNE-1034 & 2921 & 147 & 15.3 \\
Nyaikuro & 2967 & 110 & 18.4 \\
\hline Mean & 2944 & 98 & 16.9 \\
\% C.v & 0.8 & 34.1 & 16.4 \\
L.s.d & $567.8^{\mathrm{NS}}$ & $208.1^{\mathrm{NS}}$ & $8.79^{\mathrm{NS}}$ \\
\hline
\end{tabular}

* Significant at 0.05 and NS, not significant respectively by Duncan multiple range test

Table 2: Proximate composition of finger millet grain at Katangi in Machakos County

\begin{tabular}{|c|c|c|c|c|c|c|c|}
\hline \multirow[b]{2}{*}{ Genotypes } & \multicolumn{7}{|c|}{ Proximate composition of Nutrients in (\%) } \\
\hline & Crude fat & $\begin{array}{l}\text { Crude } \\
\text { protein }\end{array}$ & Total ash & Carbohydrates & $\begin{array}{l}\text { Crude } \\
\text { fiber }\end{array}$ & Moisture & $\begin{array}{l}\text { Energy } \\
\text { (Kcal/100g) }\end{array}$ \\
\hline Ateso & $2.23 \mathrm{a}$ & $6.46 \mathrm{~b}$ & 2.84 & 78.46 & 8.48 & 9.91 & 327.96 \\
\hline Gulu-E & $2.18 \mathrm{a}$ & $6.53 b$ & 2.755 & 77.29 & 6.53 & 11.25 & 323.07 \\
\hline FMV-1 & $1.98 \mathrm{ab}$ & $6.9 \mathrm{~b}$ & 2.812 & 78.11 & 7.00 & 10.19 & 326.5 \\
\hline KNE-479 & $1.27 \mathrm{~b}$ & $8.42 \mathrm{a}$ & 2.85 & 75.57 & 7.84 & 11.90 & 315.88 \\
\hline KNE-1034 & $1.62 \mathrm{ab}$ & $7.4 \mathrm{ab}$ & 2.975 & 76.69 & 6.53 & 11.31 & 320.56 \\
\hline Nyaikuro & $1.62 \mathrm{ab}$ & $7.54 \mathrm{ab}$ & 2.822 & 76.27 & 8.59 & 11.74 & 318.81 \\
\hline Means & 1.83 & 7.21 & 2.842 & 77.07 & 7.71 & 11.05 & 322.15 \\
\hline$\% \mathrm{CV}$ & 20 & 2.6 & 5.8 & 2.2 & 21 & 14.9 & 1.7 \\
\hline L.s.d & $0.685^{*}$ & $1.128 *$ & $0.302^{\mathrm{NS}}$ & $3.146^{\mathrm{NS}}$ & $2.946^{\mathrm{NS}}$ & $3^{\mathrm{NS}}$ & $2.684^{\mathrm{NS}}$ \\
\hline
\end{tabular}

*, Significant at 0.05 and NS, not significant respectively, respectively by Duncan multiple range test:

\subsection{Amino acids contents}

Amino acids contents significantly differed among genotypes $(\mathrm{p}<0.05)$ (Table 3$)$. Only genotype KNE479 had the lowest isoleusine contents compared to the others genotypes. Genotypes FMV-1 and Ateso had the highest leusine contents while genotype KNE-479 had the lowest. Genotypes Nyaikuro had the highest lysine contents followed by KNE-1034 while the lowest lysine contents were observed in genotypes KNE-479, Ateso and Gulu-E. The highest methionine contents were observed in genotype Ateso, in contrast, genotypes KNE-479 and Gulu-E had the lowest. Highest phenylalanine contents were observed in genotype Nyaikuro followed by Ateso and FMV-1 while genotype KNE-1034 followed by KNE-479 had the low contents. Threonine contents were highest in genotypes Ateso, Gulu-E and FMV-1 compared to genotypes KNE-1034 and KNE-479 which had the lowest contents. The highest cystein contents were observed in genotypes Nyaikuro followed by Ateso while the lowest contents were observed in genotypes KNE-479 and Gulu-E. 
Variation of Nutritional and Anti-Nutritional Contents in Finger Millet (Eleusine coracana (L.)

Table 3: Amino acid contents of finger millet genotypes in Katangi at Machakos County

\begin{tabular}{|c|c|c|c|c|c|c|c|}
\hline \multirow[b]{2}{*}{ Varieties } & \multicolumn{7}{|c|}{ Essential amino acids in finger millet (ug/g) } \\
\hline & Isoleusine & Leusine & Lysine & Methionine & $\begin{array}{l}\text { Phenylala } \\
\text { nine }\end{array}$ & Threonine & Cystein \\
\hline Ateso & $2.700^{\mathrm{a}}$ & $6.45^{\mathrm{a}}$ & $0.277^{\mathrm{c}}$ & $1.977^{\mathrm{a}}$ & $1.820^{\mathrm{b}}$ & $1.947^{\mathrm{a}}$ & $0.190^{\mathrm{ab}}$ \\
\hline Gulu-E & $2.363^{\mathrm{a}}$ & $3.54^{\mathrm{bc}}$ & $0.193^{c}$ & $0.350^{\mathrm{c}}$ & $1.617^{\mathrm{c}}$ & $1.820^{\mathrm{a}}$ & $0.140^{\mathrm{c}}$ \\
\hline FMV-1 & $2.723^{\mathrm{a}}$ & $6.74^{\mathrm{a}}$ & $0.943^{\mathrm{b}}$ & $1.653^{\mathrm{ab}}$ & $1.770^{\mathrm{b}}$ & $1.763^{\mathrm{a}}$ & $0.177^{\mathrm{b}}$ \\
\hline KNE-479 & $1.650^{\mathrm{b}}$ & $3.04^{\mathrm{c}}$ & $0.327^{\mathrm{c}}$ & $0.437^{\mathrm{c}}$ & $1.230^{\mathrm{d}}$ & $1.023^{\mathrm{c}}$ & $0.123^{\mathrm{c}}$ \\
\hline KNE-1034 & $2.650^{\mathrm{a}}$ & $4.05^{\mathrm{b}}$ & $1.300^{\mathrm{ab}}$ & $0.943^{\mathrm{bc}}$ & $1.317^{\mathrm{d}}$ & $1.187^{\mathrm{c}}$ & $0.173^{\mathrm{b}}$ \\
\hline Nyaikuro & $2.633^{\mathrm{a}}$ & $4.04^{\mathrm{b}}$ & $1.767^{\mathrm{a}}$ & $1.307^{\mathrm{ab}}$ & $1.977^{\mathrm{a}}$ & $1.420^{\mathrm{b}}$ & $0.210^{\mathrm{a}}$ \\
\hline Mean & 2.453 & 4.64 & 0.801 & 1.111 & 1.622 & 1.527 & 0.167 \\
\hline$\%$ C.v & 3.7 & 2.1 & 18.1 & 2.8 & 0.6 & 3.6 & 7.3 \\
\hline L.s.d & $0.3551 *$ & $0.781 *$ & $0.5342 *$ & $0.706^{*}$ & $0.1441 *$ & $0.1773^{*}$ & $0.0218^{*}$ \\
\hline
\end{tabular}

*, Significant at 0.05 and NS, not significant respectively, respectively by Duncan multiple range test

\subsection{Anti-nutritional contents}

Except for tannins, significant differences in all anti-nutritional contents were observed among the genotypes $(\mathrm{p}<0.05)$ (Table 4). Tannin contents didn't differ among genotypes. Highest ferulic acid contents were observed in genotype Nyaikuro. Genotype KNE-479 had the lowest ferulic acid content. P-hydroxybenzoic acid content was highest in genotype Ateso and lowest in genotypes KNE-1034. Genotypes KNE-479 followed by Ateso and Gulu-E had the highest sinapic acid contents while the least contents were observed in genotype FMV-1. The highest syringic acid contents were observed in genotype Ateso, while lowest were observed in genotype KNE-1034. Genotypes Nyaikuro and FMV-1 had the highest vanilic acid contents while genotypes Gulu-E and KNE-1034 had the lowest contents.

Table 4: Variability of anti-nutritional content in finger millet genotypes at Katangi in Machakos County

\begin{tabular}{lrrrrrr}
\hline \multirow{2}{*}{ Varieties } & \multicolumn{7}{c}{ Anti-nutritional contents (ug/g) } \\
\cline { 2 - 7 } & $\begin{array}{c}\text { Tannins } \\
\mathbf{( m g} / \mathbf{k g})\end{array}$ & Ferulic acid & P-hydroxybenzoic acid & $\begin{array}{c}\text { Sinapic } \\
\text { acid }\end{array}$ & Syringic acid & Vanilic acid \\
\hline Ateso & 4088.0 & $68.56^{\mathrm{c}}$ & $21.14^{\mathrm{a}}$ & $12.95^{\mathrm{ab}}$ & $12.46^{\mathrm{a}}$ & $13.25^{\mathrm{d}}$ \\
Gulu-E & 2761.0 & $76.08^{\mathrm{b}}$ & $10.86^{\mathrm{c}}$ & $12.50^{\mathrm{b}}$ & $5.27^{\mathrm{d}}$ & $17.25^{\mathrm{c}}$ \\
FMV-1 & 5389.0 & $74.98^{\mathrm{b}}$ & $10.53^{\mathrm{c}}$ & $10.61^{\mathrm{d}}$ & $7.16^{\mathrm{c}}$ & $22.13^{\mathrm{a}}$ \\
KNE-479 & 4168.0 & $61.04^{\mathrm{e}}$ & $7.72^{\mathrm{d}}$ & $13.17^{\mathrm{a}}$ & $9.69^{\mathrm{b}}$ & $19.28^{\mathrm{b}}$ \\
KNE-1034 & 3239.0 & $66.34^{\mathrm{d}}$ & $6.55^{\mathrm{e}}$ & $11.51^{\mathrm{c}}$ & $2.33^{\mathrm{e}}$ & $16.82^{\mathrm{c}}$ \\
Nyaikuro & 3637.0 & $78.27^{\mathrm{a}}$ & $17.37^{\mathrm{b}}$ & $11.05^{\mathrm{cd}}$ & $5.21^{\mathrm{d}}$ & $22.61^{\mathrm{a}}$ \\
\hline Mean & 3880 & 70.88 & 12.36 & 11.96 & 7.02 & 18.56 \\
\% C.v & 35.2 & 1.2 & 2.9 & 2.5 & 4.7 & 2.0 \\
L.s.d & $\mathrm{NS}$ & $1.543^{*}$ & $0.747^{*}$ & $0.546^{*}$ & $0.598^{*}$ & $0.672^{*}$ \\
\hline
\end{tabular}

* Significant at 0.05 and NS, not significant respectively, respectively by Duncan multiple range test

\subsection{Correlations}

\subsubsection{Correlation of Minerals and Anti-nutritional factors}

The correlation between finger millet $\mathrm{Ca}$ and all anti-nutritional contents was not significant. There was a significant correlation $(\mathrm{p}<0.05)$ between $\mathrm{Fe}$ and all the anti-nutritional contents (Table 5). Iron content was positively correlated with P-hydroxybenzoic, syringic and sinapic acids. Negative correlations were observed between Fe and tannin, vanilic and ferulic acids. Iron and ferulic acid had a strong negative correlation. Zinc showed significant correlation with all the anti-nutritional contents. Anti-nutritional contents P-hydroxybenzoic, syringic and sinapic acids had a positive correlation with $\mathrm{Zn}$. A strong positive correlation was observed between $\mathrm{Zn}$ and P-hydroxybenzoic acid. Negative correlation was observed between $\mathrm{Zn}$ and tannins, vanilic and ferulic acids.

\subsubsection{Correlation of proximate composition and Anti-nutritional contents}

Correlation between finger millet calorific value and anti-nutritional contents was not significant. However, there was a positive but weak correlation between calorific value and tannins and ferulic acids (Table 6). There was no correlation between crude protein and all the anti-nutritional contents. Carbohydrate content was weak but positively correlated to tannins and syringic acid. Fiber contents had a weak and positive 
correlation with vanilic, sinapic and ferulic acid. Even though weak, only tannins were positively correlated to moisture content.

Table 5: Correlation between anti-nutritional contents and mineral contents in finger millet genotypes at Katangi in Machakos County

\begin{tabular}{lrrr}
\hline & Calcium & Iron & Zinc \\
\hline Tannins & $-0.461 \mathrm{NS}$ & $-0.021^{*}$ & $-0.114^{*}$ \\
P-hydroxybenzoic acid & $0.150 \mathrm{NS}$ & $0.016^{*}$ & $0.326^{*}$ \\
Vanilic Acid & $-0.126 \mathrm{NS}$ & $-0.151^{*}$ & $-0.101^{*}$ \\
Syringic Acid & $-0.173 \mathrm{NS}$ & $0.050^{*}$ & $0.240^{*}$ \\
Sinapic Acid & $-0.115 \mathrm{NS}$ & $0.216^{*}$ & $0.116^{*}$ \\
Ferulic Acid & $0.322 \mathrm{NS}$ & $-0.321^{*}$ & $-0.036^{*}$ \\
\hline
\end{tabular}

*, Significant at 0.05 and NS, not significant respectively, respectively by Duncan multiple range test

Table 6: Correlation between anti-nutritional factors and proximate analysis components in finger millet genotypes at Katangi in Machakos County

\begin{tabular}{|c|c|c|c|c|c|}
\hline $\begin{array}{l}\text { Anti-nutritional } \\
\text { Contents }\end{array}$ & Calorific value & Crude Protein & Carbohydraetes & Fibre & Moisture \\
\hline Tannins & $0.031^{*}$ & $0.138 \mathrm{NS}$ & $0.015^{*}$ & $-0.081 \mathrm{NS}$ & $0.04968^{*}$ \\
\hline $\begin{array}{l}\text { P-hydroxybenzoic } \\
\text { Acid }\end{array}$ & $-0.313 \mathrm{NS}$ & $-0.387 \mathrm{NS}$ & $0.105 \mathrm{NS}$ & $0.188 \mathrm{NS}$ & $-0.243 \mathrm{NS}$ \\
\hline Vanilic Acid & $0.136 \mathrm{NS}$ & $0.330 \mathrm{NS}$ & $-0.205 \mathrm{NS}$ & $0.039^{*}$ & $0.206 \mathrm{NS}$ \\
\hline Syringic Acid & $-0.463 \mathrm{NS}$ & $-0.067 \mathrm{NS}$ & $0.005 * *$ & $0.120 \mathrm{NS}$ & $-0.161 \mathrm{NS}$ \\
\hline Sinapic Acid & $-0.079 \mathrm{NS}$ & $0.083 \mathrm{NS}$ & $-0.059 \mathrm{NS}$ & $0.023 *$ & $0.075 \mathrm{NS}$ \\
\hline Ferulic Acid & $0.032 *$ & $-0.4437 \mathrm{NS}$ & $0.134 \mathrm{NS}$ & $0.045 *$ & $-0.123 \mathrm{NS}$ \\
\hline
\end{tabular}

* Significant at 0.05 and NS, not significant respectively, respectively by Duncan multiple range test.

\subsubsection{Correlation of Amino acid and Anti-nutritional contents}

Amino acids leusine, threonine, methionine, phenylalanine and cystein were not significantly correlated to all the anti-nutritional contents (Table 7). Amino acid lysine was weakly correlated to P-hydroxybenzoic acid, while amino acid isoleusine was negatively and weakly correlated to vanilic acid.

Table 7: Correlation between amino acids and anti-nutritional contents in Katangi at Machakos County

\begin{tabular}{|c|c|c|c|c|c|c|c|}
\hline & Lysine & Leusine & Isoleusine & Threonine & Methionine & Phenylalanine & Cystein \\
\hline Tannins & $0.151 \mathrm{NS}$ & $0.312 \mathrm{NS}$ & $0.112 \mathrm{NS}$ & $0.145 \mathrm{NS}$ & $0.450 \mathrm{NS}$ & $0.126 \mathrm{NS}$ & $0.141 \mathrm{NS}$ \\
\hline P-hydrobenzoic acid & $-0.001 *$ & $0.479 \mathrm{NS}$ & $0.406 \mathrm{NS}$ & $0.594 \mathrm{NS}$ & $0.613 \mathrm{NS}$ & $0.790 \mathrm{NS}$ & $0.623 \mathrm{NS}$ \\
\hline Vanilic acid & $0.542 \mathrm{NS}$ & $-0.112 \mathrm{NS}$ & $-0.046^{*}$ & $-0.285 \mathrm{NS}$ & $-0.067 \mathrm{NS}$ & $0.209 \mathrm{NS}$ & $0.149 \mathrm{NS}$ \\
\hline Syringic acid & $-0.560 \mathrm{NS}$ & $0.393 \mathrm{NS}$ & $-0.228 \mathrm{NS}$ & $0.326 \mathrm{NS}$ & $0.360 \mathrm{NS}$ & $0.163 \mathrm{NS}$ & $-0.077 \mathrm{NS}$ \\
\hline Sinapic acid & $-0.699 \mathrm{NS}$ & $-0.350 \mathrm{NS}$ & $-0.594 \mathrm{NS}$ & $-0.069 \mathrm{NS}$ & $-0.271 \mathrm{NS}$ & $-0.377 \mathrm{NS}$ & $-0.587 \mathrm{NS}$ \\
\hline Ferulic acid & $0.345 \mathrm{NS}$ & $0.244 \mathrm{NS}$ & $0.5466 \mathrm{NS}$ & $0.572 \mathrm{NS}$ & $0.194 \mathrm{NS}$ & $0.794 \mathrm{NS}$ & $0.502 \mathrm{NS}$ \\
\hline
\end{tabular}

* Significant at 0.05 and NS, not significant respectively, respectively by Duncan multiple range test.

\subsection{Mineral content}

\section{Discussion}

Minerals are inorganic nutrients usually required in small amounts from less than 1 to $2500 \mathrm{mg}$ per day and their presence is necessary for maintenance of certain physiochemical processes which are essential to life ([18]). In this study the key minerals $\mathrm{Fe}, \mathrm{Ca}$ and $\mathrm{Zn}$ were determined due to their nutritional importance ([6]). All the six varieties analyzed showed presence of $\mathrm{Ca}, \mathrm{Fe}$ and $\mathrm{Zn}$ in variable quantities irrespective of their yield potential and genetic differences. However, all quantities of the three minerals analyzed didn't differ among the finger millet genotypes. Other studies by ([19]) disagree with our findings where a variation among genotypes in the profile of trace minerals was reported. ([19]) attributed the variation among genotypes in minerals contents to differences in ecological conditions from which the finger millet genotypes originated. The results of this study also differ with findings of other workers who reported differences in Ca content among 36 finger millet genotypes ([20]). Lack of variability in mineral content among the genotypes of this study occurred possibly because few genotypes were used or they originated from related genetic pool.

\subsection{Proximate composition}


Proximate composition comprise of biological materials needed by a human beings in major constituents and includes; crude fat, crude protein, carbohydrates, moisture and energy ([6]). Of all the proximate composition analyzed it is crude fat and protein contents that differed among the genotypes. Presence of fat in seeds affects storability and brewing quality of finger millet; more fat content leads to the grain to become rancid ([21]) Therefore the lower the fat content the longer the storage life and better malting properties. Genotypes Ateso and Gulu-E (local landraces) and FMV-1 (improved varieties form KARI) had high crude fat content. It is of interest to note that fat content increased with increase in yield as the above genotypes also were the high yielding genotypes.

([22]) observed finger millet genotypes that were brown in colour had lower protein contents compared to documented white genotypes that are known to have higher protein contents. Even though all the genotypes used for analysis were brown in color in this study, the protein contents among the genotypes significantly differed with improved genotype from ICRISAT and KARI having the highest contents. This variation of proteins could be as a result of genetic improvement in these particular genotypes ([9]).

In this study the local land races had high fat content but a contrastingly low protein. Conversely, the improved ICRISAT genotypes had low fat contents but high protein contents. International Crop Research for Semi-Arid Tropical major works are geared towards improving finger millet for drought tolerance. Part of the improvements is increasing the genes and metabolites identified for drought tolerances which are protein in nature therefore cumulatively elevating protein contents in these genotypes ([25]).

\subsection{Essential Amino acid}

Essential amino acids cannot be produced by the body and must be derived from food. Essential amino acids are important for proper functioning of the body; increase muscle mass, regulates blood sugar and helps muscle recover after exercise, supplies the body with energy, enables the synthesis of carnitine, plays an important role in the production of hormones, antibodies and enzymes essential for the synthesis of haemoglobin and glutathione that fights against free radicals among other functions ([24]). In this study the local landrace Ateso followed by the KARI developed genotypes FMV-1 and Nyaikuro had high isoleusine, leusine, methionine, threonine and cysteine amino acid contents. High levels of phenylalanine were observed in genotypes Nyaikuro and Ateso. These suggest that local land races are rich in essential amino acids and that should be taken advantage of in breeding programs. In contrast the improved ICRISAT genotypes were lacking in some essential amino acids though rich in total crude protein.

\subsection{Anti-nutritional contents}

Accumulation and variation of anti-nutritional factors is a biochemical response aimed at protecting finger millet against the prevailing harsh abiotic conditions (drought) and biotic stresses (pest's attacks) ( [9]). According to ([9]), tannins contents are higher in dark colored varieties followed by brown varieties and least in white coloured varieties. The genotypes used for analysis were all brown in colour and could be the possible reason for lack of variation in tannin contents. Genotype Ateso had the highest P-hydroxybenzoic, sinapic and syringic acids, while Nyaikuro had high ferulic and vanilic acids. Except for genotype KNE-479 with highest sinapic acid contents, the ICRISAT developed genotypes had the lowest anti-nutritional contents. Variation of phytic acid contents observed among the genotypes could be as a result of adaptation of different genotypes to the different prevailing environmental conditions ([4]). ([25]) identified phytic acid as the main organic storage form of phosphate in finger seed grain which is released in high amounts in drought conditions. Based on the genetic adaptability of different genotypes to prevailing drought conditions, varying amounts of phytic acid contents were produced and accumulated in the seed according adaptability. Our observations mirrors to those reported by ([10]) who recorded variation of anti-nutritional factors for the genotypes screened under different ecological conditions.

\subsection{Correlations}

Correlation of nutritional and anti-nutritional nutrients showed both positive and negative relations across all the parameters correlated. Anti-nutritional contents were not correlated to $\mathrm{Ca}$, carbohydrates, calorific value, fiber, moisture content and amino acids. Tannins, vanilic acid and ferulic acid were negatively correlated to Fe and Zn. Our results agree with finding from other studies by ([26]) who reported variation in relationship between physiochemical and functional properties in finger millet. Therefore breeders should breed for genotypes with low anti-nutritional contents of tannins, vanilic acid and ferulic acid.

\section{Conclusion}

Our study revealed that the local landraces of finger millet were rich in fat content; while the improved genotypes were rich in crude protein contents. It was further revealed the local landraces were also rich in 
essential amino acids. It was further shown that $\mathrm{Fe}$ and $\mathrm{Zn}$ contents were negatively correlated to tannins, vanilic acid and ferulic acid.

\section{Acknowledgements}

The authors acknowledge Regional Universities Forum for Capacity Building in Agriculture (RUFORUM) for their financial support to fund this research through the University of Nairobi. We thank Kenya Agricultural Research Institution (KARI) and International Crops Research Institute for Semi-Arid Tropics (ICRISAT) for their collaboration and allowing their materials to be used for this research.

\section{References}

[1] S., Mbithi-Mwikya, J., Van-Camp, Y., Yiru and A., Huyghebaert, Nutrient and anti-nutritional changes in finger millet (Eleusine corocana) during sprouting, Lesbenson-Wiss.U. Technical 33, 2000, 9-14.

[2] M.M., Dida, S., Srinivasachary, J.L., Bennetzenn, M.D., Gale and K. M. Devos, Population structure and diversity in finger millet (Eleusine coracona) germplasm, Tropical plant Biology 1, 2008, 131-141.

[3] K., Lorenz, Tannins and phytate content in proso millets (Panicum miliaceum), Cereal Chem. 60. 1983, 424-426.

[4] National Research Council (NRC), Lost crops of Africa. Volume 1: Grains, Washington, D.C.: National Academy Press, 1996.

[5] V., Kumar, A.K., Sinha, H.P.S., Makkar and K., Becker, Dietaty roles of phytate and phytase in human nutrition, Food chemistry, 120, 2003, 945-956.

[6] P. Singh, and R.S., Raghuvanshi, Finger millet for food and nutritional security, African Journal of Food Science, 6(4), 2012, 7784.

[7] J.R.N., Tylor, T.J., Schober and S.R., Bean, Novel food and non-food uses for sorghum and millets, Journal of Cereal Science, 44, 2006, 252-271.

[8] M.K., Sharavathy, A., Urooj, and S., Puttaraj, Nutritionally important starch fractions in cereal based Indian food preparations, Food Chemistry. 70, 2001, 107-111.

[9] I., Léder, Sorghum and millets, in cultivated plants, primarily as food sources, [Ed György Füleky], in: Encyclopedia of Life Support Systems (EOLSS), Developed under the auspices of the UNESCO, Eolss Publishers, Oxford ,UK, [http://www.eolss.net], 2004.

[10] B.K. Shashi, S., Sunanda, H., Shailaja, A.G., Shankar and T.K., Nagarathna, Micronutrient composition, anti-nutritional factors and bioaccessibility of iron in different finger millet (Eleusine coracana) genotypes, Karnataka Journal of Agricultural Sciences, 20(3), 2007, 583-585.

[11] R., Jaetzold, H., Schmidt, Z.B., Hornet and C.A. Shisanya, Natural conditions and farm information, Farm management handbook of Kenya., 2nd edn. Vol.11/C. Eastern Province, Ministry of Agriculture/GTZ, Nairobi, Kenya, 2006.

[12] Association of Official Analytical Chemists (AOAC), Official methods of analysis, 17 ${ }^{\text {th }}$ Edn., AOAC: Washington D.C.,USA, 2000.

[13] M.W., Helen, Influence of processing on anti-nutrients and production of some value added finger millet based products, master of Science thesis, Addis Ababa University, 2001.

[14] M. A., Aynandis, Effects of extrusion operating conditions on aflatoxin reduction and product characteristic of corn-peanut flakes, master of Science thesis, Addis Ababa University, 2010.

[15] J.L., Guyot, L.S., Jouanneau, G.R., Boaventura, N., Maillet and C., Lagane, Clay mineral composition of river sediments in river sediments in Amazon Basin, Catena, 71, 2007, 340-356

[16] E.S., Humphries, Mineral components and ash analysis. Modern methods of plant analysis, 1: 468-502. Berlin: Springer Verlag, 1956.

[17] V.L., Singleton, and J.A., Rossi, Colorimetry of total phenolics with phosphomolybdicphoshotungstic acid reagents, American. Journal of Entomology and Viticulture 16, 1965, 144-158.

[18] K.O., Soetan, C.O., Olaiya and O.E., Oyewole, The importance of mineral elements for humans, domestic animals and plants: A review, African Journal of Food Science 4(5), 2010, 200-222, [http://www.academicjournals.org/ajfs]

[19] Y.G., Deosthale, V., Nagarajan and K.C. Pant, Nutrient composition of some varieties of ragi (Eleusine coracana), The Indian Journal of Nutrition and Diettetics, 7(2), 1970, 80-84.

[20] P., Panwar, M., Nath, V.K., Yadav and A. Kumar, Comparative evaluation of genetic diversity using RAPD, SSR and cytochome P450 gene based markers with respect to calcium content in finger millet (Eleusine coracana L. Gaertn.), Journal of Genetics, 89, 2010,121-133.

[21] S., Serna-Saldivar and L.W., Rooney, L.W., Structure and chemistry of sorghum and millets. In: Dendy D.A.V. (ed.), Sorghum and Millets: Chemistry and Technology. American Association of Cereal Chemists Inc., St. Paul, Minnesota, USA, p. $100,1995$.

[22] T.K., Virupaksha, G., Ramachandra and D., Nagaraju, Seed proteins of finger millets and their amino acid composition, J. Sci. Food Agric., 26, 1975, 1237-1246.

[23] D., Bartels and R. Sunkar, Drought and salt tolerance in plants, Critical review of plant science, 24, 2005, $23-48$.

[24] K., Takahashi, A., Montecinos, K., Goubanova and B., Dewitte, ENSO regimes: Reinterpreting the canonical and Modoki E1 Niño, Geophysical Research Letters. VOL. 38, L10704, doi:10. 1029/2011GL047364, 2011.

[25] Y.G., Deosthale, The nutritive value of foods and the significance of some household processes. $\underline{\text { http: } / / w w w . u n u . e d u}$., 2002, p. 6 .

[26] M., Hidvegi and R. Lasztity, R., Phtyic acid content of cereals and legumes and interaction with proteins, Periodical polytechnic ser. Chem. Eng. 46 (1-2), 2002, 59-64. 